\title{
Urban Regeneration for Sustainable Economic Growth: the study of Boro Bazaar in Khulna, Bangladesh
}

\author{
S. M. Reazul Ahsan*, Rumana Asad, A.F.M. Ashraful Alam \\ Khulna University Khulna, Bangladesh \\ *r_ahsanku@yahoo.com
}

\begin{abstract}
The major dynamic driving forces of cities in developing countries are economic and social forces to change the urban system with the growing demand of population and urbanization. Of course, the problems are different and unique to a particular city based on the city growth pattern, economic and social character. Khulna, the third largest metropolitan city in Bangladesh with 1.2 million populations within 45.6 square kilometer was developed as a medium scale industrial city since 1950s. Previously the city economy was completely established on river-based trade and the city developed around the river port locally named "Boror Bazaar" means big market place. The changing city form gave Boro Bazaar the shape of mixed-use zone rather solely commercial or business zone. Now, as a central economic hub in the city centre, Boro Bazaar needs to be more dynamic to response to the city economy and its growth pattern. For last one decade, Boro Bazaar has faced compact unplanned haphazard development even along the riverside just to meet the demand of rapid urbanization process. Therefore, it has become an urban challenge to revitalize the Boro Bazaar area to make more effective response to the rapid economic growth and to ensure better urban environment for the residents, businesspersons and the employers.
\end{abstract}

Key words: Urban Regeneration, Urban Form, Developing Country

\section{Introduction}

During the last half of the twentieth century, instability due to demographic changes, job redistribution allocation of public private partnerships has made redevelopment for cities more contested (Alam, 2011). Regeneration efforts of cities employed different development paradigms from 'Urban' to 'Suburban' and finally to 'Neo-Traditional' practice which create new neighborhoods that are high in density and provide a mixture of land uses, intends to provide a pedestrian oriented environment and fosters sense of community (Sands, 2000). Many of the approaches of urban regeneration are being tested to achieve sustainability around the world in forms of community participation, area based regeneration, place making, economic restructuring, physical regeneration, development of Brownfield sites, bottom up governance practice, public private partnership etc. 'It has been continually questioned for years in order to identify urban regeneration scope of cities by defining their focal points, politics and priorities put forward' (Yalcinta \& Kilinc, 2010). Cities in developing countries are commonly characterized by the highest density of inhabitants, agglomeration of industrial assets and production, social and technological infrastructure; dynamic informal economic sector under the shadow of its formal concentration. Coupled with largely uncontrolled spatial expansion; poor governance resulting in inefficient and exhausted utilities and public services; unregulated and disparate land and property markets and insufficient housing provision they accommodate higher existence of informal settlement as repercussions resulting to a higher ecological strain to the environment. However, all the cities are complex in nature and dynamic. The dynamic urban system reflects many driving forces like social, economical and environmental forces those change the urban form with the time and need. Urban regeneration situates taking into account those driving forces to reform the urban system to meet with the present time and future demand. Therefore, it may be suggested that urban regeneration is an outcome of all or any of those driving forces of the urban system. Usually the major dynamic driving forces of developing cities are economic and social forces to change the urban system with the growing demand of population and urbanization.

The domination of economy in the developing countries is commercial, medium scale industrial and informal sector rather than heavy industries or the formal tertiary service sectors of those post-industrial cities. Those 
informal economic sectors act as pull factor for internal rural-urban migration for developing countries and change the existing urban pattern. Therefore, urban regeneration of the old inner city areas takes place as an active planning tool to meet the growing economic demand and to accommodate the population influx. Of course, all the urban problems are different and unique to a particular city based on the city growth pattern, and its economic and social character. At the same time, location of a city has an important role to make the city unique both in its social and economic perspective. Therefore urban regeneration is likely to be particular to a specific location and characteristic of the city (Roberts, 2000). Khulna is a linier city along the rivers of the Rupsha and the Bhairab in Bangladesh depending highly on river based trade economy. It was developed as a medium scale industrial city since 1950s because of its suitable location and the availability of raw materials for industrial development. The second largest seaport in Bangladesh is also in Khulna region to support the industrial development and trade. Khulna was converted to a municipality from a formal township in 1884 during the British colonial regime. During 1950s and 1960s, the city got importance as an industrial hub with many industries like newsprint mills, shipyard, jute mills, match factories, jute bailing presses, hardboard mills, etc. In the year 1990 the Khulna Municipality came under the formal institution body of City Corporation (Murtaza, 2001). Before the industrial development in 1950s, the city economy was completely based on river-oriented trade and the city developed around the locally named "Boror Bazaar" which means big market place. Boro Bazaar has established along the river Bhairab during the British colonial regime to operate and control the local retail and wholesale business. Still today, Boro Bazaar is the main economic hub for the city that controls the total retail and wholesale market and plays the most significant role in the economy. Unfortunately, throughout the history Boro Bazaar has been developing in an unplanned way and in a form of mixed commercial and residential zone relates to those commercial occupants. Owing to its advantageous location, it eventually became the most congested zone in the city. At this wake of time, it is very important to determine a suitable urban regeneration approach to address the urban problems within it and at the same time how it may continue as a historical and important economic hub for the Khulna City through retaining its long established indigenous settlement tectonics.

Being the main economic hub in the city, Boro Bazaar needs to be more dynamic in responding to the city economy and its growth pattern. Therefore, it has been a major concern for the Khulna City Corporation (KCC) to reorganize the whole Boro Bazaar area under urban regeneration process to make it a better place for the residents and therefore it may be able to handle the commercial activities more efficiently to cope with the city's economic need and future growth. The current paper attempts to find the possible approaches of urban regeneration through review of urban regeneration in history through literature survey. Furthermore, it advocates guidelines to regenerate Boro Bazaar area to make it an efficient commercial centre with a better living environment for the residents and better landmark for the city; considering the heritage and the existing condition.

\section{Theoretical review of urban regeneration}

The priorities to put forward urban regeneration changed over time and space. In the 1950s, the focus was mainly to uphill the quality of physical environment. The focus changed to social emphasis in 1960s, increased the economic concern in 1970s. During the decade of 1980s private sector investment got attention through 'creating confidence for managing efficient redevelopment schemes'(Yalcinta \& Kilinc, 2010). Until date, it shifted to a more strategic management focus of multi-sectors and the citizens. 'Realization of visions of a sustainable city depends on cities being able to identify the issues and approaches best suited to their particular needs and circumstances' (Weingaertner, 2010). That is why the best way to future strategies for sustainable urban regeneration is to look back to the experiences and take lessons from them. At the beginning of the 20th century, urban pollution and related unhygienic living condition were major concerns of urban regeneration without any distinct focus other than development before the large-scale war damage had to be handled after 1940s (Gale, 1984; Latham \& Swenarton, 1999) in their inner cities due to the affluence of industrialization. Government led physical renewal were initiated through the form of large scale slum clearance (Couch, Fraser, \& Percy, 2003; Falk, 1993). By 1960s, physical revitalization got readjustments through local community involvement and decentralizing (soft urban renewal) governance mechanism of the municipalities and increasing private sector partnership (Brindley, Rydin, \& Stoker, 1996; Couch, et al., 2003; Kleinman \& Whitehead, 1999; Roberts \& Hugh, 2000). During 1970s and 1980s cultural policy started to serve social and political agendas rather than economic ones (Kong, 2000). In the late 1990s culture and 
economy came into convergence through expanding city marketing techniques (García, 2004) through providing 'emotional fuel' (Tibbot, 2002) for tourists to successful destination branding (Evans, 2003) toward value added regeneration capacity (Scott, 2000). However, Klunzman (2004) recognized that many of the culture-led projects started with poetry and ended up with merely real estate (Evans, 2005).

By the 1980s the focus of public response shifted drastically towards 'aggregate economic growth' (Healey, Davoudi, O'Toole, Tavsanoglu, \& Usher, 2002; Kearns \& Philo, 1993; Rosenthal, 1980; Yalcinta, 2008; Yalcinta \& Kilinc, 2010) through private sector involvement. Under the ideology of privatization 'the prestige model' (Loftman \& Nevin, 1994), kind of 'flagship' (Bianchini, Dawson, \& Evans, 1992; Healey, et al., 2002) regeneration projects emerged to revive the fortune of deprived urban areas through attracting property developer and inward investors with the changing modes of accumulation in cities (Raco, 2003). However 'prestige projects while providing a useful mechanism for securing the physical regeneration of fragments of urban areas, also serve to mask the more deep-seated and fundamental social and economic division within cities' (Loftman \& Nevin, 1995). The 1990s was a major turnaround to the environmental objectives as concept of sustainable urban development was introduced. Society became more concern about the effectiveness of regeneration schemes through reducing gentrification from the inner city areas, enhancing economic reintegration of disadvantaged areas and improvement of the overall spatial context; thus triangulating society, economy and environment to gain sustainability. Today, as compiled by Yalcinta and Kilinc (2010) an efficient regeneration process is expected to promote smart growth, generate sufficient revenue and return from underutilized and abandoned property, create new job and business opportunity, community empowerment, addressing people's real needs, increase environment quality, remove blight through providing quality of life for all. Not only that, the top down, centralized and hierarchical past governance mechanism is being revisited and transformed into a more decentralized, reticular and interactive discourse (Hill, 1994; Schenkel, 2006).

Study Area: Khulna is the third largest metropolitan city and the 2nd port entry in Bangladesh. The city is located in the south-western part of the country between $22047^{\prime} 16^{\prime \prime}$ to $22052^{\prime}$ north latitude and 89031'36" to 89034'35" east longitude (Nahiduzzaman, Saroar, \& Ahmed, 2004). Among the ancient cities of Bangladesh, which carry their past glorious and remarkable heritage, Khulna is one placed on top. The city started its journey with commercial activities beside riverbank, later the city mostly renowned for its industrial activities in the world map. The growing industrial economy and increase in seaport-based trade resulted in a sharp increase in city population from 0.62 million to 1.2 million from the year 1991 to 2002. In 1884 Khulna was as a municipality with 6000 population with an area of $4.86 \mathrm{sq} . \mathrm{km}$. and after 100 years later the city becomes the third City Corporation of Bangladesh with an area of 45.65 sq. km with 1.2 million (Islam \& Karim, 2006).

Figure 1: Locational Pattern of Boro Bazaar area (Ahsan \& Rahman, 2005)

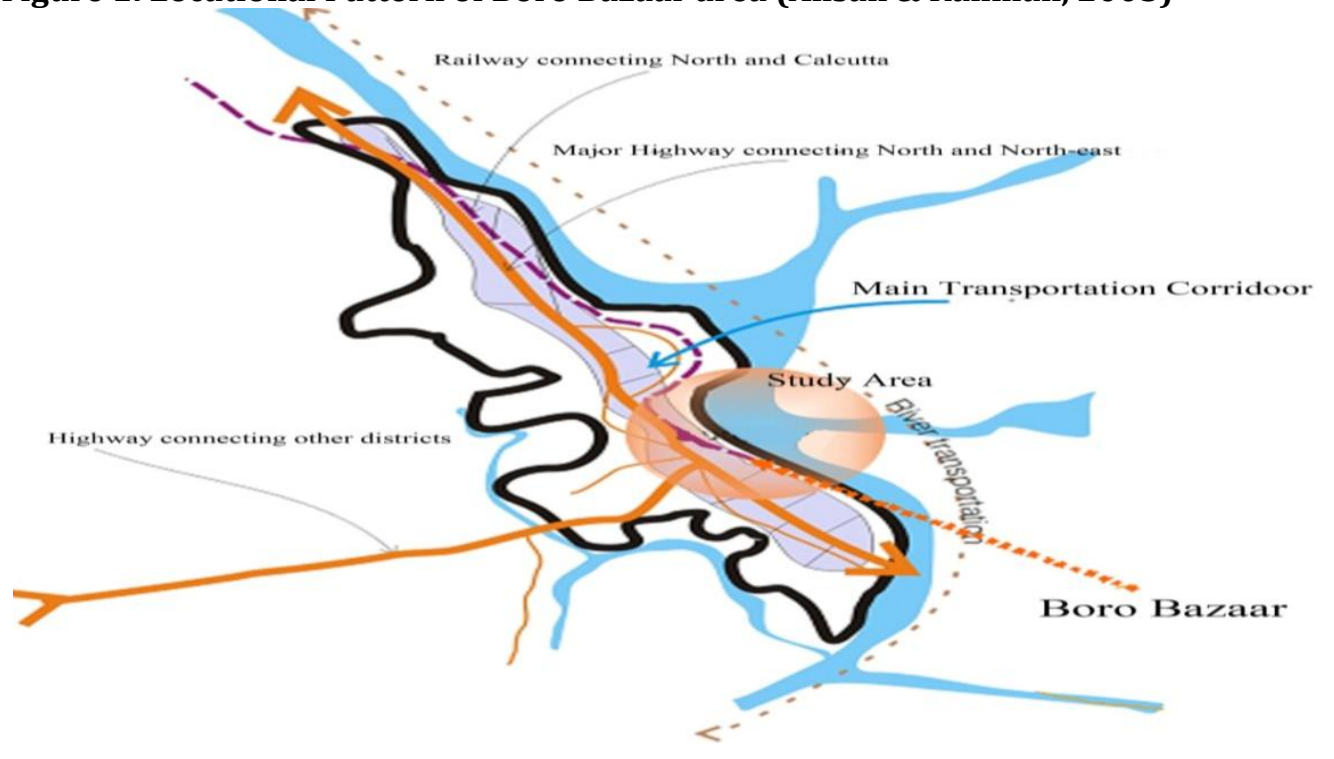


Boro Bazar Area: Since the British colonial period, the Boro Bazaar was the main commercial and trade center. During 1950s to 1970s, the trade multiplication effect of rapid industrialization in Khulna region transformed the social, economic and urban fabric of Khulna city more as an industrial base rather commercial. The changing city form gave Boro Bazaar the shape of mixed-use zone rather than solely commercial or business zone. The international highway between India and Bangladesh, the divisional highways, railways and inter district water ways crossing over Boro Bazaar and their trade links make it highly potential and important for both national and international trade and commerce. Figure 1 shows the geographical location and location advantage of the study area.

Existing Land-Use in Boro Bazaar: The existing land use pattern in Boro Bazaar area is completely mixeduse type. The land use pattern is composed of mainly trade commerce, residential hotels and residential areas. Followings are the broad classification of existing land use pattern in Boro Bazaar.

Table 1: Land distribution in Boro Bazaar according to land use type

\begin{tabular}{llll}
\hline Type & & No of Structures & Percentage \\
\hline Residential & & 158 & 18.00 \\
& Retail & 87 & 12.00 \\
Commercial & Wholesale & 115 & 15.00 \\
& Service & 8 & 1.25 \\
Other Commercial (mixed) & Storage & 65 & 9.20 \\
Industrial & & 144 & 19.50 \\
Squatter Settlement & 1 & 0.15 \\
Road (in sq ft) & 36 & 3.50 \\
Open Space( in sq ft) & & $57024 \mathrm{ft}^{2}$ & 3.50 \\
\hline
\end{tabular}

Source: (Shamima, 2005)

'Other commercial (mixed)' use in Table 1 normally covers both residential and commercial use including commercial storages or residential hotels in one place sharing the same structure. According to the Table 01, mixed land use covers the maximum land share in Boro Bazaar and that is about 20 percent of the land and next is the residential area that covers 18 percent of the total land. Over the decades, Boro Bazaar has developed haphazardly to keep the pace with the growing economic demand in Khulna city. Therefore, the area has developed with narrow roads, congested building and shops, vulnerable informal structures along the riverside and with lower end urban facilities like drainage water supply and other urban services. The overall land use pattern makes the area inefficient to respond to the growing economy of the city and to meet the living standard for the local residents. Therefore, the redevelopment through regeneration now becomes a core issue to make the Boro Bazaar area more economically viable, a better living environment for the residents and an urban landmark for Khulna city. Following is the land use map in Boro Bazaar area.

Figure 2: Existing land use pattern in Boro bazaar area (Shamima, 2005)

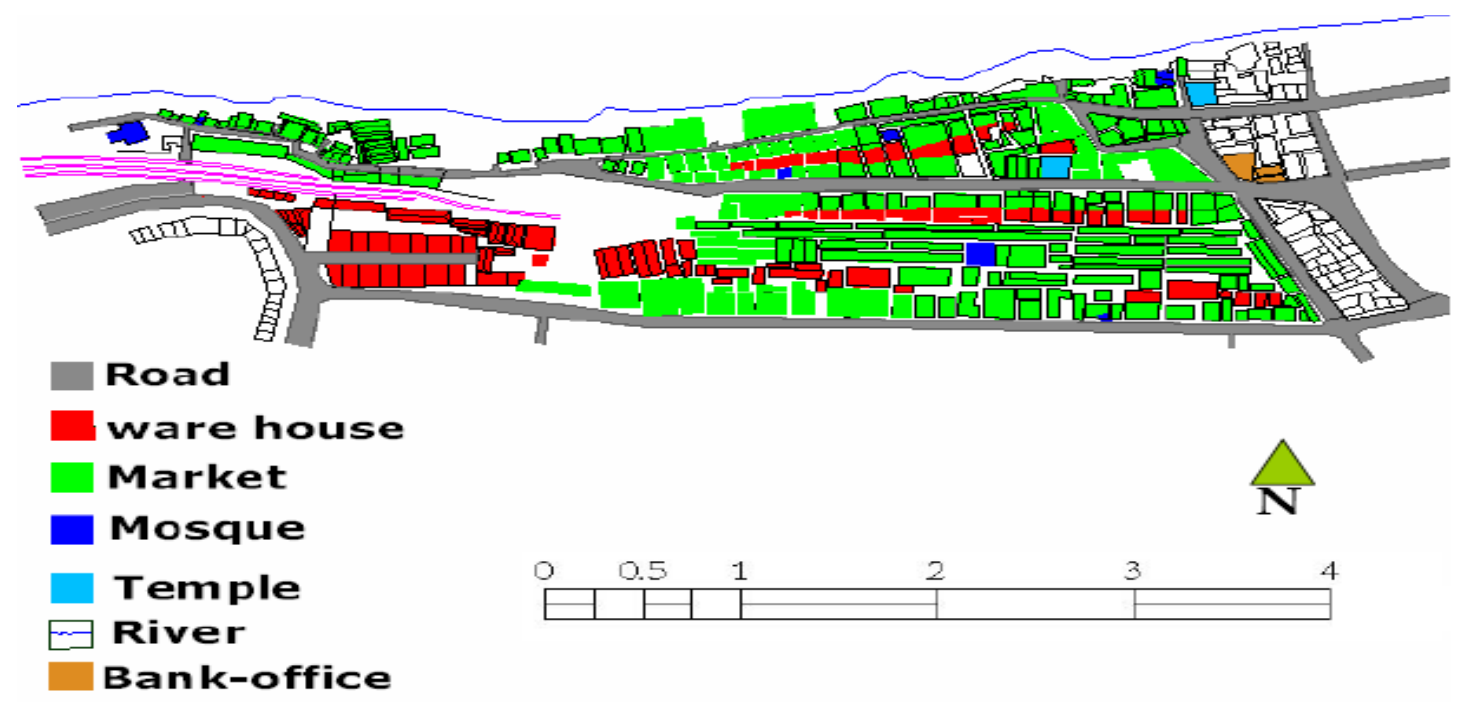


Figure 3: Existing Pattern of Structures in Boro Bazaar (Shamima, 2005)

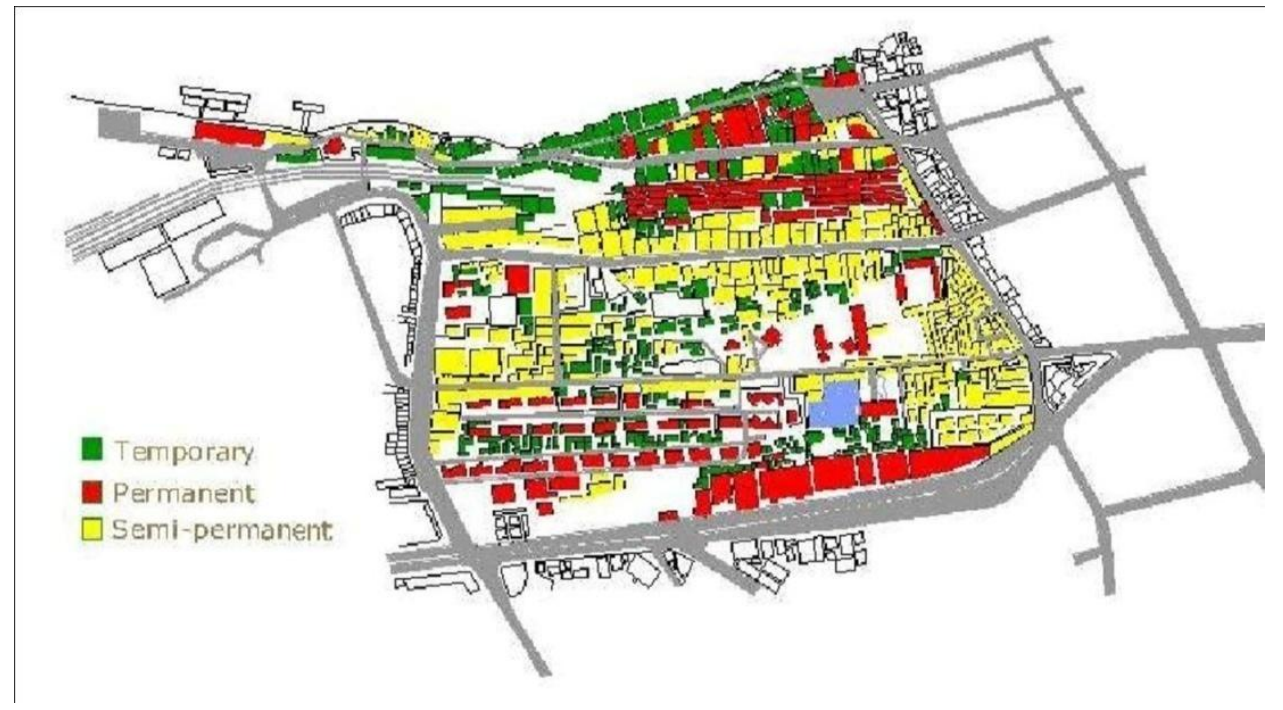

Most of building structures in the Boro Bazaar area are temporary and semi-permanent in nature, made of tin, asbestos and indigenous construction materials like bamboos. Some mixed-use commercial buildings are constructed by concrete tin and asbestos. Most of the temporary structures are constructed along the riverside and serve as retail shops. The semi-permanent structures are mostly used for residential purposes; some are also used as residential hotels and wholesale storages. The permanent structures are used for wholesale and commercial purpose like banks and insurance companies as well wholesale storages. Briefly, as depicted in Figure 03, the existing pattern of the structures containing the land use of Boro Bazaar is as such $-34 \%$ structures are of temporary construction, $18 \%$ of permanent structures and the biggest percentage of $48 \%$ comprises of semi-permanent structures. Unplanned land distribution, different structural types and concentric growth make the whole Boro Bazaar area a compact urban centre with mixed-use pattern. The following photographs are showing the existing setup of Boro bazaar area.

\section{Photograph 1: Existing set up of Boro Bazaar area (Ahsan \& Rahman, 2005)}
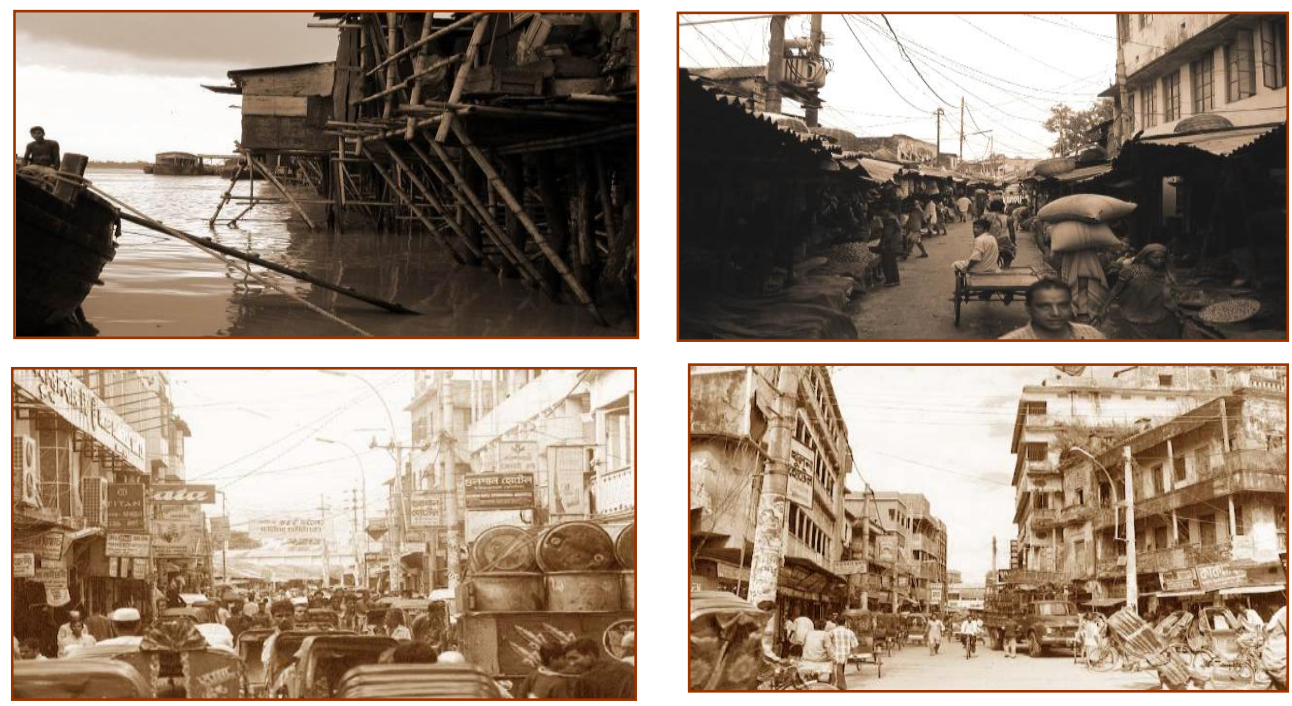

The existing building structures are quite old and some of them built during British regime and had not been renewed afterwards. Some modern structures had been built after the late 1990s and some had been renovated recently. However, a big number of unauthorized constructions make the whole area more congested. The unauthorized temporary constructions along the riverside are the most vulnerable. Those 
unauthorized and unplanned developments make the whole area too congested to provide urban services to ensure better environment as a residential area as well as an effective commercial area to meet the economic challenges of the city.

\section{Trade and Commercial Activities in Boro Bazaar}

Trade activities in Boro Bazaar area are mainly characterized by wholesale and retail. Boro Bazaar links the southern part of Bangladesh through operation and control over the wholesale and retail traders. Most of the wholesale shops demand extensive storage facilities, therefore, they need more land and are arranged along the riverside to handle loading and unloading of the goods from river based transport. The wholesale markets are also established on the open land, which is owned by the Bangladesh Railway Authority under long-term leasing around the Boro Bazaar area. Rapid economic growth after 1971, less restricted open government land with low tax and illegal occupancy exacerbated horizontal expansion in the area. Therefore, it caused traffic congestion around the city centre including most of the arterial roads across Boro Bazaar. According to Reza (Reza, 1999), maximum number of trade units in Boro Bazaar area is retail shops (51\%), then the wholesales trade units $(22 \%)$ followed by the storage capacity (20\%). The service facilities like banks and insurance companies have a limited share (only 7\%) in the area. As a city center and main economic hub the trade units in Boror Bazaar handle a huge amount of financial flow every month and provide both direct and indirect employment for the urbanites. The following tables represent the financial flow and employment market in Boro Bazaar.

Table 2: Financial flow of Boro Bazaar in 1991 (Reza, 1999)

\begin{tabular}{ll}
\hline Employment type & Number of Person \\
\hline Direct & $15,000-20,000$ \\
Indirect & $30,000-35,000$ \\
Others & $1000-15,00$ \\
\hline
\end{tabular}

Table 3: Employment opportunity in Boro Bazaar in 1999 (Ahsan \& Rahman, 2005)

\begin{tabular}{lll}
\hline Business type & Daily (US\$.avg) (,000) & Monthly (US\$.avg) (,000) \\
\hline Retail & 45.4 & 118 \\
Wholesale & 23.6 & 60 \\
Commercial & 118.6 & 363.6 \\
Total & 187.7 & 541.6 \\
\hline
\end{tabular}

The Boro Bazaar area generates revenue for the local government through income taxes and land taxes as well Bangladesh Railway gets yearly revenue through log-term land leasing for wholesale and storage. The local government also leases the river port areas (locally called ghats) to export and import goods within the country and to the neighboring India. Following diagram shows river port areas (Ghat) through which both the wholesale and retail trades control the export and import business and the local and central government earn revenue by long-term leasing policy.

Figure 4: Ghats along Boro Bazaar (Ahmed, Rahman, Hasan, Ahmed, \& Rahman, 2010)

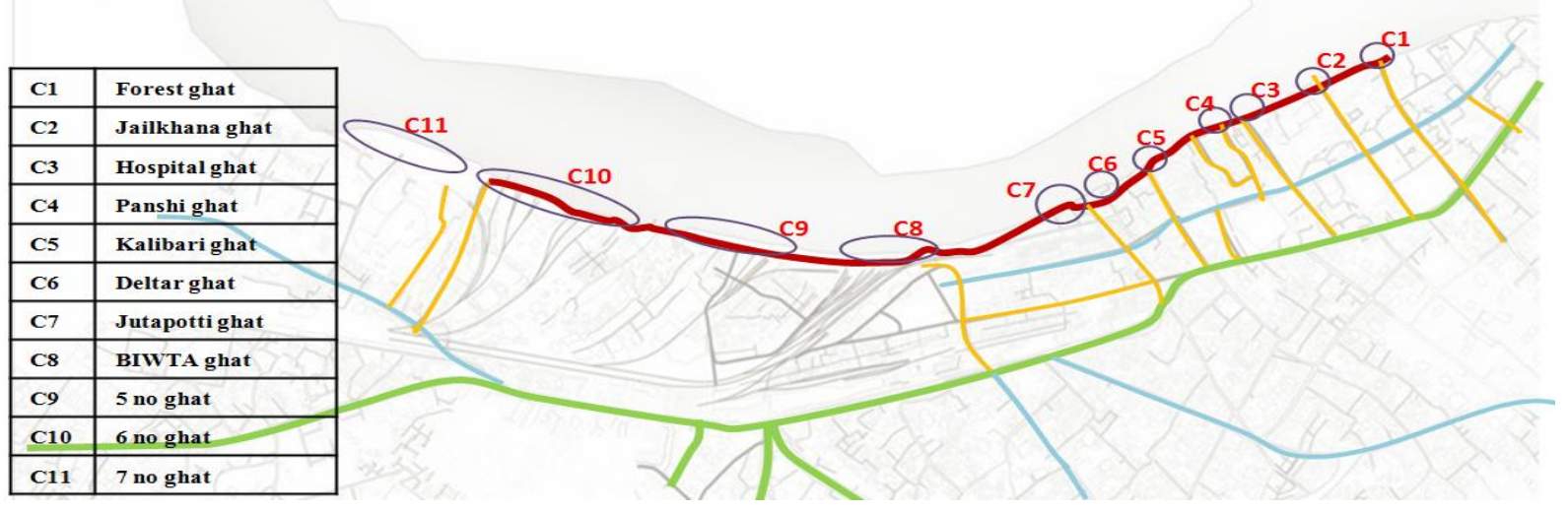


The following photos show how the local river ports in Boror Bazaar operate export and import business based on waterways and generate revenue for the government.

\section{Photograph 2: The local River Ports along Boro Bazaar (Ahsan \& Rahman, 2005)}
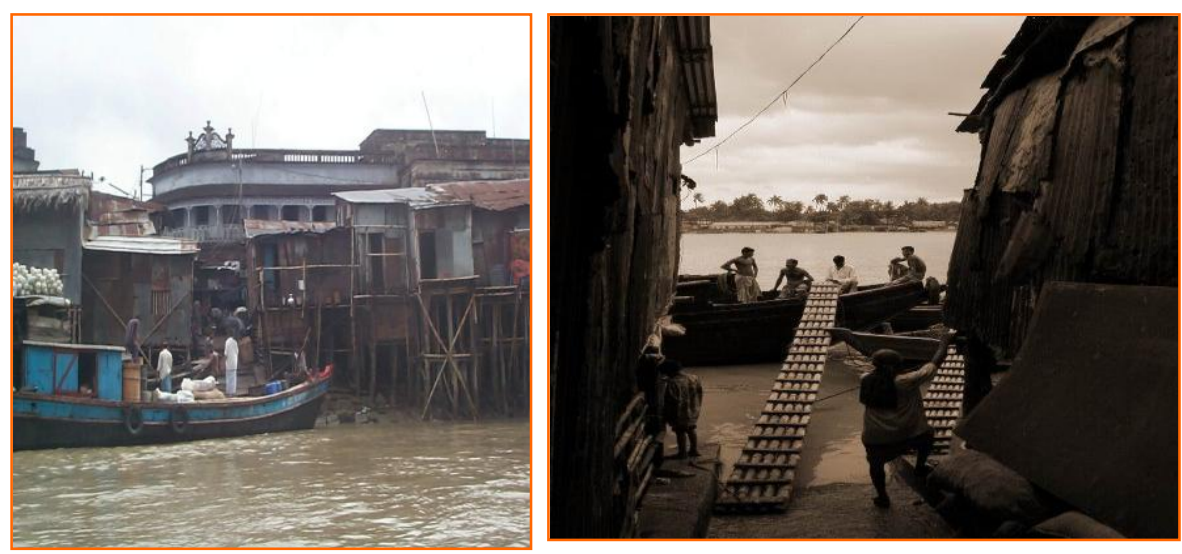

As mentioned that Boro Bazaar is one of the major income sources for the local and central government through land and income taxes as well as by leasing the port areas. Following data are representing the revenues earned by the government from the Boro Bazaar area according to the Khulna City Corporation in 2001.

Table 4: Yearly Revenue Collected by different Authorities in Boro Bazaar

\begin{tabular}{|c|c|}
\hline Revenue Collecting Authority & Amount in USD/Year \\
\hline $\begin{array}{l}\text { Land Tax collected by Khulna City Corporation (KCC) } \\
\text { (expected yearly demand } 72,272 \text { USD) }\end{array}$ & 25,426 USD \\
\hline $\begin{array}{l}\text { Income Tax collected by other local government authorities } \\
\text { Revenue earned by Bangladesh Railway by leasing land } \\
\text { wholesale shops and storages }\end{array}$ & $\begin{array}{l}43,336 \text { USD } \\
\text {,30, } 831 \text { USD } \\
\text { (From wholesale shops) } \\
7,330 \text { USD } \\
\text { (From Storage) }\end{array}$ \\
\hline $\begin{array}{l}\text { Revenue collected by Bangladesh Inland Water Transport } \\
\text { Corporation (BIWTC) }\end{array}$ & $\begin{array}{l}20,945 \text { USD } \\
\text { (From shops along river banks) } \\
22,290 \text { USD } \\
\text { (From local Ghats) } \\
\text { 5, 014 USD } \\
\text { (From passenger ferries) }\end{array}$ \\
\hline
\end{tabular}

Source: KCC 2001.

Because of economic importance, over the decades, different redevelopment actions had been taking place in Boro bazaar to make it more efficient and to respond the growing economic demand for increasing the national and local revenue. The Khulna City Master plan of 1998 also stated clear guidelines for redevelopment of Boro Bazaar. The present situation is so congested in Boro Bazaar that it is almost impossible to provide better urban services, like water supply and sanitation. The roads are too narrow to provide fire protection services in case of any fire hazards. Therefore it has become an urban challenge to regenerate the area to ensure a better environment along with the economic engine turned on.

\section{Urban Regeneration Framework for Boro Bazaar}

As suggested by the theoretical framework of urban regeneration, an efficient regeneration process is expected to promote smart growth, generate sufficient revenue and return from underutilized property, create new job and business opportunity, community empowerment, addressing people's real needs, increase environment quality, remove blight through providing quality of life for all, keeping these things into consideration, this segment of the paper proposes the broad framework for urban regeneration of Boro 
Bazaar and its vicinity. The whole idea is how to keep the growing pace of economic engine thus providing a better urban environment to its occupants. It has been evident that unplanned, though compact development makes the whole area too congested to provide better urban services and to ensure a better living and working environment for the resident, businessmen and the employers/employees working at Boro Bazaar. Therefore three major areas have been considered in this paper for rearrangement and redevelopment under the urban regeneration framework for the Boro Bazaar area, i.e., wholesale shops and storages areas, the riverfront and networks of road.

Rearrangement of Wholesale Shops and Storages: The wholesale and the storages area need to be rearranged in a planned way to minimize the compact development and land use. The Boro Bazaar area is now expanding horizontally and occupies the land owned by Bangladesh Railway. At the same time to meet the growing economic demand furthermore, the wholesale shops and storage capacity need to be extended in a planned way. Existing land use in the Boro Bazaar area needs to be reorganized for re-allocating space for the wholesale and storage sites. The land use alteration is possible through using the vacant land by dividing the whole market place in to different blocks based on their nature of business agglomeration. Furthermore, the existing unattended vacant land of Bangladesh Railway around the Boro Bazaar area could be used for storages and wholesale shops under different short and long-term lease basis. It could generate revenue for the local government to provide and maintain the urban services in the market place and minimize the congestion. The unattended vacant land owned by the Bangladesh Railway could be the land bank for redevelopment process for the wholesale and storages in Boro Bazaar area (see photograph 03). The following diagram shows the existing vacant and unutilized land marked with red circles within and around the Boro Bazaar area owned by the Bangladesh Railway.

\section{Figure 5: Unattended available vacant land within Boro Bazaar. Source: Author}

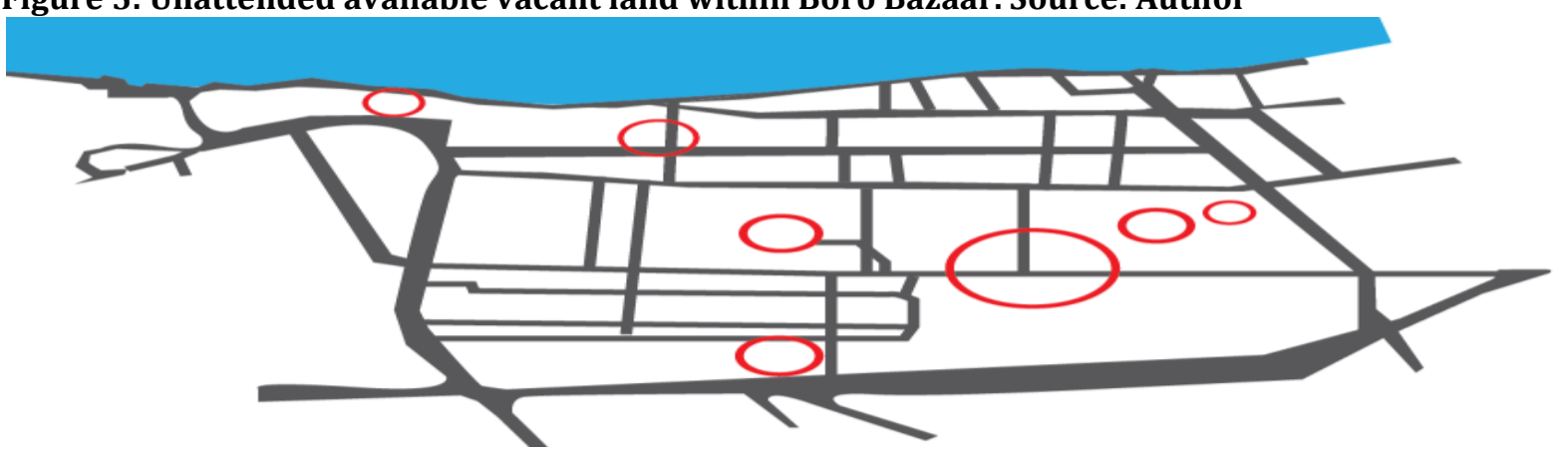

Photograph 3: Unattended vacant land of Bangladesh Railway (Ahsan \& Rahman, 2005)
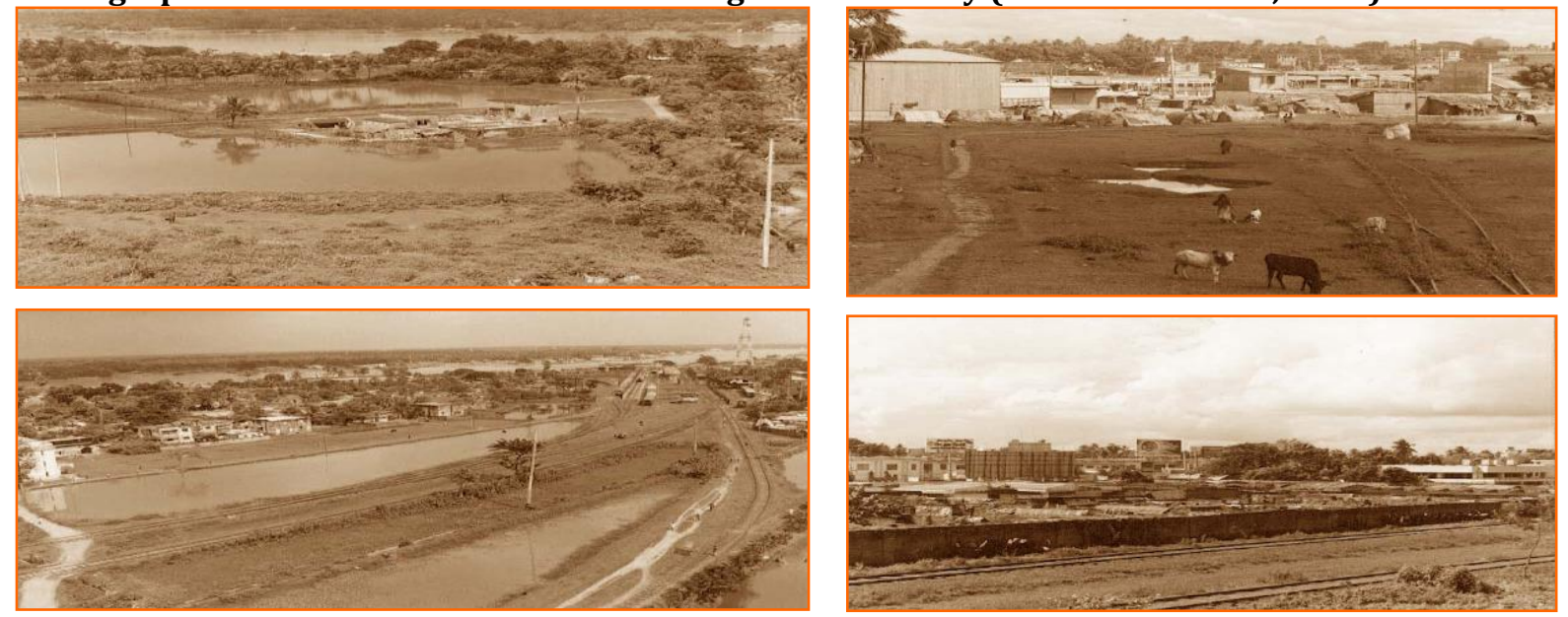

The advantages of such development are faster and effective. As land is owned by the government, its acquisition and development could be easier. Furthermore those lands are closely connected with rail and 
water transport network. Therefore, there will be no extra expense for transport network development. The area needs to be rearranged according to the use and capacity and at the same time tax need to be imposed based on the area and use, which will ensure revenue for the government and make the market more efficient to handle the city economy. The following map in figure 06 shows the proposed development in the Boro Bazaar area in different blocks based on different purposes. The proposed plan considers the horizontal expansion of Boro Bazaar area that will cover the government vacant land around the Bazaar area and owned by the Bangladesh Railway. In this plan block $\mathrm{G}$ will serve the wholesale and storages purposes, block $\mathrm{E}$ and block F will use as retail market place whereas, block C and D will use for amenities and recreational area for the urbanites.

Figure 6: Proposed plan for redevelopment of wholesale and storages (Ahmed, et al., 2010)

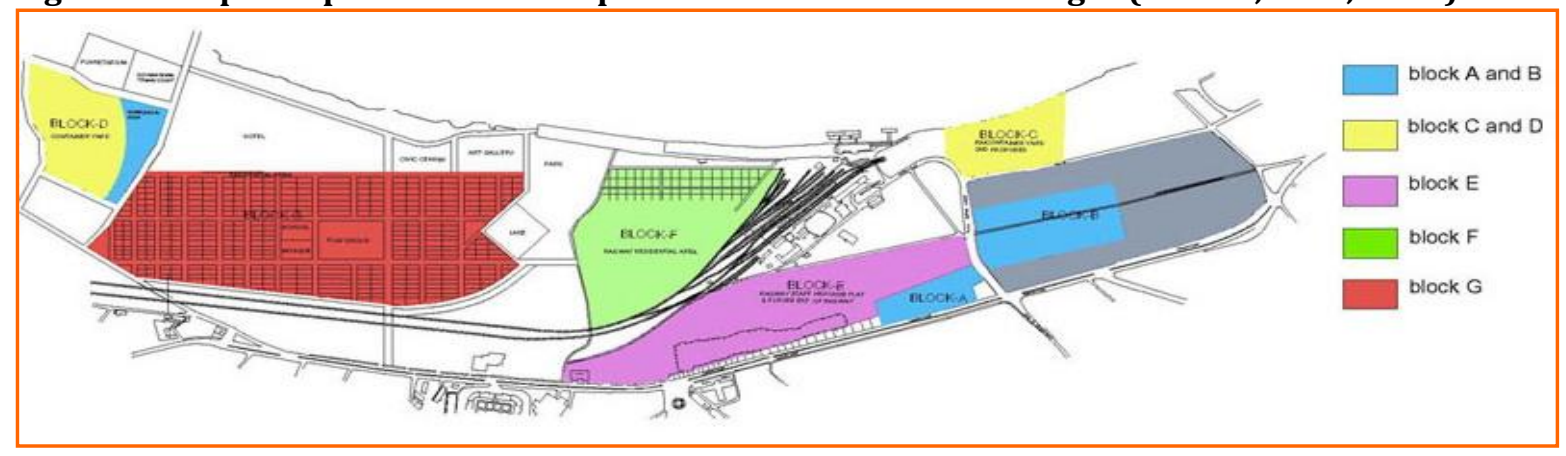

Riverfront Development: A good number of retail shops had developed along the riverbank just to meet the growing demand in the city. Even some wholesale shops were also established along the river just to minimize the goods handling and transfer cost from the port to their storages. Moreover the congested developments of the shops make the inner roads and access ways too narrow to move vehicles or even narrower for the buyers and other users (see photograph 04).

\section{Photograph 4: Narrow passes in Boro Bazaar area (Ahsan \& Rahman, 2005)}
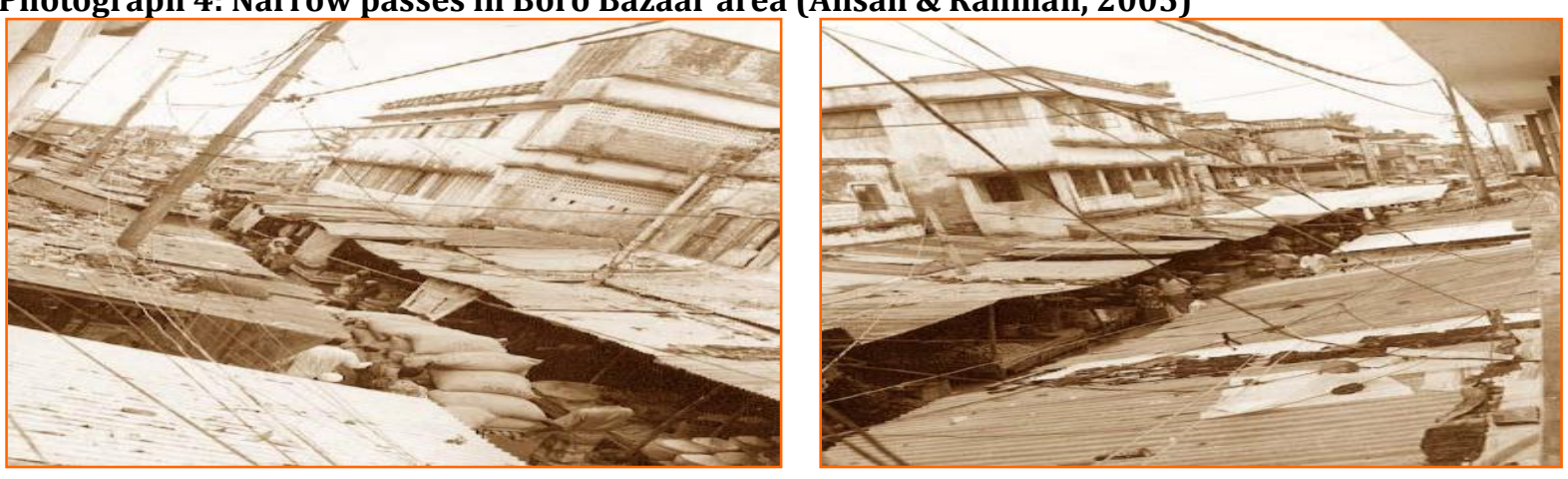

Furthermore the riverbank along the Boro Bazaar area is mainly used for transporting goods and local ferry service. There is no development control along the riverfront side. Therefore the riverfront along Boro Bazaar has been developed for retails and good handling. Under the regeneration framework, the riverfront needs to be developed as a recreational and urban breathing space, except at the port areas. The unauthorized ports also need to be reduced with development control to create more open space and to ensure city aesthetics. The open land generated by the rearrangement of the wholesale area would be used for ensuring easy access within the market place and to make the area a better working place. The riverfront development may be a long-term process but to meet the future needs it has to be started now. Better urban design will provide better urban life to the occupants in the area. The regeneration processes not only take place to meet the economic growth rather also meet the urban demand and to ensure better urban environment. 
Figure 7: Existing road network system in Boro Bazaar (Shamima, 2005)

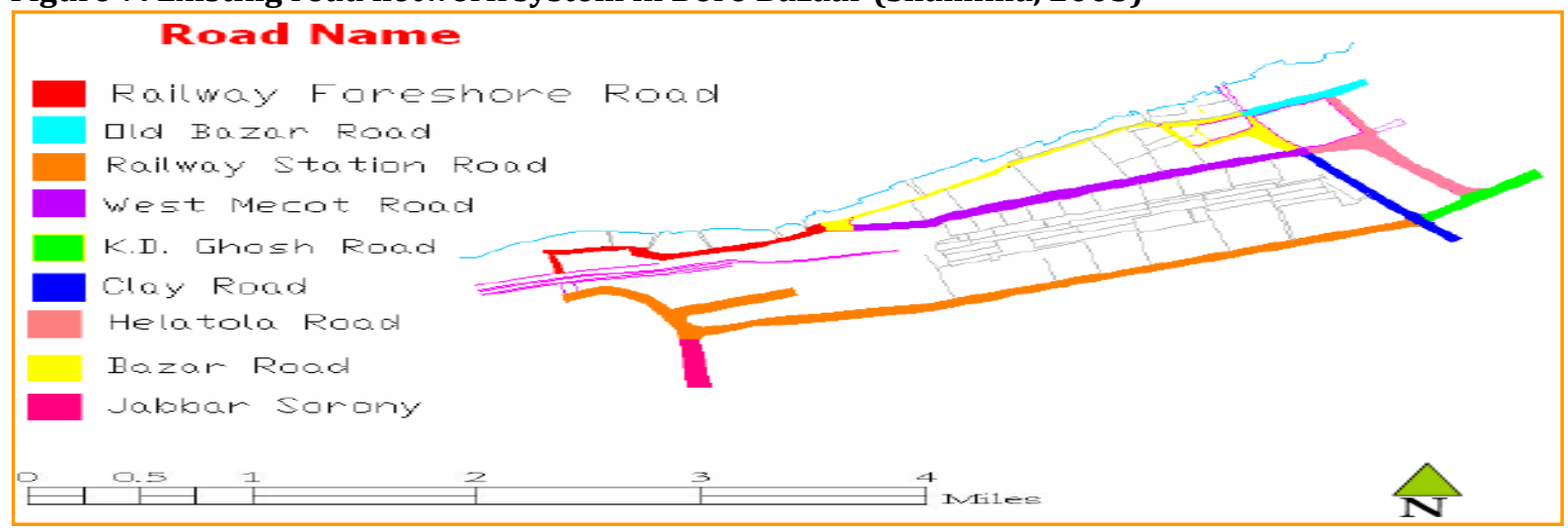

Improvement of Road Networks: Boro Bazaar area is connected with three major arteries (see figure 07); therefore the revitalization program on the circulation system and traffic movement has to be rearranged to minimize the traffic congestion in the vicinity. The first focus is needed to maintain the hierarchy of roads through separating different forms of traffic. The present road networks are not in a position to support the growing transport demand in the area and narrow enough to cause traffic congestion and provide poor services. Therefore under the regeneration framework, transport network especially the road networks need to be prioritized. The major issues need to be considered for redevelopment of road networks are as follows:

- Reorganize the mode of transportation and impose traffic control

- Relocate zones for loading and unloading

- Facilitate the informal business agglomeration without blocking traffic flow

- New parking zone for consumers who use private mode

- Identify new zone for temporary dwellers

- Utilize the river embankment as effective pedestrian traffic along river

The main market place needs to be free from traffic flow to minimize congestion. The wholesale shops and the storage services should have their own goods handling unit to get their products from the loading and unloading zone. Vehicle restrictions need to be imposed as well based on vehicle weight and size within the market place through different time zoning. The road network revitalization process completely depends on policy, command and control approach.

\section{Conclusion}

Urban regeneration process is a comprehensive and long-term planning tool that covers not only the physical development but also the economic growth and the future expansion of the city. Under the regeneration framework, it is important to consider the context, its historical evolution process and the future growth trend. Therefore, the regeneration process is also related to the historically constructed urban morphology and regeneration initiative has to protect the originality along with meeting the standardized demands. Within the Boro Bazaar urban regeneration framework, it is also important to maintain the originality of the area. The originality covers the present economic importance of the site, past historic value of the area as an economic hub; the image ability of Khulna city with its industrial heritage and how it could accommodate the future growth of both population and economy. The process has to protect the mixed use zoning character and the economical importance of the area. The proposed plans are based on the physical importance of the area and the role they play in the 'bazaar' morphology. Based on those issues, three major areas have been proposed to consider under the regeneration framework for a better urban life of the occupants and to ensure economic importance of the 'Boro Bazaar' itself. Nevertheless, an urban development framework is needed to meet the regeneration challenges through recognizing the interwoven nature of social, economic and environmental well-being in a cohesive manner through prescribing the working principles of how various departments would maintain co-ordination and partnership (Alam, 2011). 


\section{References}

Ahmed, I., Rahman, M. S., Hasan, R., Ahmed, K. \& Rahman, M. (2010). A Study on Embankment of Bhairab River Side near Boro Bazaar. Unpublished Studio Project. Architecture Discipline, Khulna University.

Ahsan, R. \& Rahman, H. (2005). Redevelopment of Boro Bazaar and the riverfront area of Khulna City. Paper presented at the 1st National Conference on Asian Urban Center Development.

Alam, A. F. M. A. (2011). Social Practice Spatial Forms and Sustainable Urban Regeneration - the Case of Hong Kong. Unpublished MSc Urban Planning Thesis, The University of Hong Kong, Hong Kong.

Bianchini, F., Dawson, J. \& Evans, R. (1992). Flagship projects in urban regeneration. In P. Healey, S. Davoudi, M. O'Toole, D. Usher \& S. Tavsanoglu (Eds.), Rebuilding the City: Property Led Urban Regeneration (245-255). London: Spon.

Brindley, T., Rydin, Y. \& Stoker, G. (1996). Remaking planning: the politics of urban change (2nd ed. ed.). London: Routledge.

Couch, C., Fraser, C. \& Percy, S. (2003). Urban regeneration in Europe. Oxford: Blackwell Publishing.

Evans, G. (2003). Hard-branding the cultural city-from Prado to Prada. International Journal of Urban and Regional Research, 27(2), 417-440.

Evans, G. (2005). Measure for measure: Evaluating the evidence of culture's contribution to regeneration. Urban Studies, 42(5-6), 959-983.

Falk, N. (1993). Regeneration and Sustainable Development. In J. Berry, S. McGreal \& B. Deddis (Eds.), Urban regeneration: property investment and development (161-174). London: E \& F.N. Spon.

Gale, D. E. (1984). Neighborhood revitalization and the postindustrial city: a multinational perspective. Lexington, Mass.: Heath.

García, B. (2004). Cultural policy and urban regeneration in Western European cities: lessons from experience, prospects for the future. Local Economy, 19(4), 312-326.

Healey, P., Davoudi, S., O'Toole, M., Tavsanoglu, S. \& Usher, D. (2002). Property-led urban regeneration: an assessment. In P. Healey, S. Davoudi, M. O'Toole, S. Tavsanoglu \& D. Usher (Eds.), Rebuilding the City: Property-led Urban Regeneration (275-291). London: E. \& F. N. Spon.

Hill, D. (1994). Citizens and cities: urban policy in the 1990s. London: Harvester Wheatsheaf.

Islam, K. S. \& Karim, R. (2006). The impact of the small scale real-estate business on the urbanization patterns of third world cities. RICS Research Paper, 6(3).

KCC. (2001). Khulna City Corporation Annual Income and Development Report ,2001. Khulna City Corporation, Khulna

Kearns, G. \& Philo, C. (1993). Selling places: the city as cultural capital, past and present. Oxford: Pergamon Press.

Kleinman, M. \& Whitehead, C. (1999). Housing and regeneration: the problem or the solution. National Institute Economic Review, 170(1), 78-86.

Klunzman, K. (2004). Key Note Speech in Regeneration and Renewal. Paper presented at the Intereg III Midterm Conference, Lille.

Kong, L. (2000). Culture, economy, policy: trends and developments. Geoforum, 31(4), 385-390.

Latham, I. \& Swenarton, M. (1999). Brindleyplace: a model for urban regeneration. London: Right Angle Publishers.

Loftman, P. \& Nevin, B. (1994). Prestige project developments: economic renaissance or economic myth? A case study of Birmingham. Local Economy, 8(4), 307-325.

Loftman, P. \& Nevin, B. (1995). Prestige projects and urban regeneration in the 1980s and 1990s: a review of benefits and limitations. Planning Practice and Research, 10(3), 299-316.

Murtaza, G. (2001). Environmental Problems in Khulna City, Bangladesh: a Spatio-Household Level Study. Global Built Environment Review a journal of architecture, planning, development and the environment, 1(2), 32-37.

Nahiduzzaman, K., Saroar, M. M. \& Ahmed, S. J. (2004). Assessing the urban environmental quality of Khulna city: a multilevel quantitative approach. Plan Plus a journal of Planning, Development, Urbanization and Environment, 1(2), 79-95.

Raco, M. (2003). Assessing the discourses and practices of urban regeneration in a growing region. Geoforum, 34(1), 37-55.

Reza, R. (1999). Mixed use development of urban utilities in ward 21: a study on Khulna city, Bangladesh. Unpublished Bachelor of Architecture, Khulna University, Khulna. 
Roberts, P. (2000). The Evolution, Definition and Purpose of Urban Regeneration. In P. Roberts \& S. Hugh (Eds.), Urban regeneration: a handbook (9-36). London: Sage Publications.

Roberts, P. \& Hugh, S. (2000). Urban regeneration: a handbook. London: Sage Publications.

Rosenthal, D. B. (1980). Urban revitalization. Beverly Hills, California: Sage Publications.

Sands, G. (2000). Paradigms for rebuilding the central city: urban, suburban or neo-traditional. In C. A. Brebbia (Ed.), The Sustainable city : urban regeneration and sustainability (485-494). Southampton, U.K.: WIT Press.

Schenkel, W. (2006). Urban Regeneration and Urban Governance: Trade Off Between Competitiveness and Social Cohesion. Workshop 4: Ecological Planning and Sustainable Urbanism: What Projects for What Housing. Retrieved from http://www.unil.ch/webdav/site/ouvdd/shared /Colloque\%202006/Communications/Eco-urbanisme/Theorie/W.\%20Schenkel.pdf

Scott, A. J. (2000). The cultural economy of cities: essays on the geography of image-producing industries. London: Sage Publications.

Shamima, A. (2005). Regulatory involvement and the problems in urban markets: a case study of Boro Bazaar in Khulna city. Unpublished BSc. Urban and Rural Planning, Khulna University, Khulna.

Tibbot, R. (2002). Culture club. Can culture lead urban regeneration? Locum Destination Review, 09, 71-73.

Weingaertner, C. (2010). Identifying Strategic Initiatives to Promote Urban Sustainability. Unpublished PhD Thesis, Royal Institute of Technology, Sweden, Stockholm.

Yalcinta, H. A. (2008). Evaluating the Impact of 'Urban Competitive Advantages' on Economic Revitalization of Deprived Inner Cities through a Case Study Held in Istanbul. Unpublished PhD Thesis, Izmir Institute of Technology, Izmir.

Yalcinta, H. A. \& Kilinc, G. (2010). Evaluation of Urban Regeneration Practice in Turkey in Comparison to General Framework for Managing Urban Regeneration in Developed Countries. Paper presented at the 14th International Planning History Society Conference. 